\title{
Type 2 diabetes-associated genetic variants of FTO, LEPR, PPARg, and TCF7L2 in gestational diabetes in a Brazilian population
}

\begin{abstract}
Mauren Isfer Anghebem-Oliveira',2, Bruna Rodrigues Martins', Dayane Alberton', Edneia Amancio de Souza Ramos ${ }^{3}$, Geraldo Picheth', Fabiane Gomes de Moraes Rego'
\end{abstract}

\begin{abstract}
Objective: Gestational diabetes mellitus (GDM) is a metabolic disorder that shares pathophysiologic features with type 2 diabetes mellitus. The aim of this study was to investigate the association of the polymorphisms fat mass and obesity-associated (FTO) rs1421085, leptin receptor (LEPR) rs1137100, rs1137101, peroxisome proliferator-activated receptor gamma (PPARg) rs1801282, and transcription factor 7-like 2 (TCF7L2) rs7901695 with GDM. Subjects and methods: 252 unrelated Euro-Brazilian pregnant women were classified into two groups according to the 2015 criteria of the American and Brazilian Diabetes Association: healthy pregnant women $(n=125)$ and pregnant women with GDM $(n=127)$, matched by age. The polymorphisms were genotyped using fluorescent probes (TaqMan $\left.{ }^{\circledR}\right)$. Results: All groups were in Hardy-Weinberg equilibrium. The genotype and allele frequencies of the studied polymorphisms did not show significant differences between the groups $(P>0.05)$. In the healthy and GDM groups, the $\mathrm{C}$ allele frequencies $(95 \% \mathrm{Cl})$ of the FTO rs 1421085 polymorphism were $36.8 \%$ [31-43\%] and $35.0 \%$ [29-41\%]; the $\mathrm{G}$ allele frequencies $(95 \% \mathrm{Cl})$ of the LEPR rs 1137100 polymorphism were $24.8 \%$ [19-30\%] and 22.8\% [18-28\%]; the $\mathrm{G}$ allele frequencies $(95 \% \mathrm{Cl})$ of the $L E P R$ rs 1137101 polymorphism were $43.6 \%$ [37-50\%] and $42.9 \%$ [37-49\%]; the G allele frequencies $(95 \%$ $\mathrm{Cl}$ ) of the PPARg rs 1801282 polymorphism were $7.6 \%$ [4-11\%] and $8.3 \%[5-12 \%]$; and the $\mathrm{C}$ allele frequencies (95\% Cl) of the TCF7L2 rs7901695 polymorphism were $33.6 \%$ [28-39\%] and $39.0 \%$ [33-45\%], respectively. Conclusion: The studied polymorphisms were not associated with GDM in a Brazilian population. Arch Endocrinol Metab. 2017;61(3):238-48.
\end{abstract}

Keywords

Diabetes; gestational diabetes mellitus; polymorphisms; genetic variants; genotype

\section{INTRODUCTION}

Cestational diabetes mellitus $(\mathrm{GDM})$ is a complex I metabolic disorder defined as glucose intolerance diagnosed in the second or third trimester of pregnancy (1). In Brazil, about $7 \%$ of pregnant women exhibit GDM and this prevalence is increasing in parallel with the obesity epidemic (2).

As for type 2 diabetes mellitus (T2DM), the pathogenesis of GDM is associated with insulin resistance owing to a reduction of beta cell function. In GDM, pancreatic beta cells are unable to produce enough insulin to compensate for the insulin resistance that commonly occurs during pregnancy $(3,4)$. GDM and T2DM have similar pathophysiologic features, suggesting that GDM is also a polygenic disease (5). Therefore, studies on the etiology of GDM have primarily been based on T2DM-associated genetic variants (6).

To further elucidate the genetic mechanisms underlying GDM, we selected several gene polymorphisms previously associated with T2DM: rs1421085 (fat mass and obesity associated; FTO), rs1137100 and rs1137101 (leptin receptor; LEPR), rs1801282 (peroxisome proliferator-activated receptor gamma; PPARg), and rs7901695 (transcription factor 7-like 2; TCF7L2) and investigated their association with GDM. To our knowledge, this is the first study involving these genetic variants and GDM in a Brazilian population. Figure 1 illustrates the genes and polymorphisms studied.

FTO is a protein-coding gene located at the chromosome region 16q12.2 and associated with the 


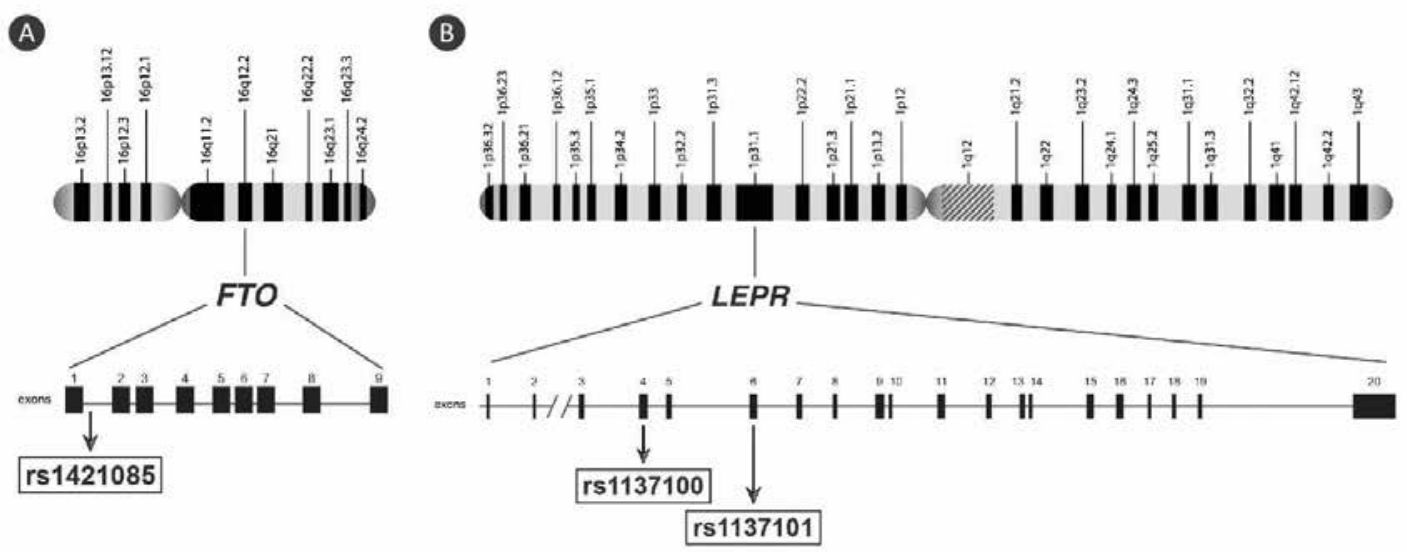

C

(D)
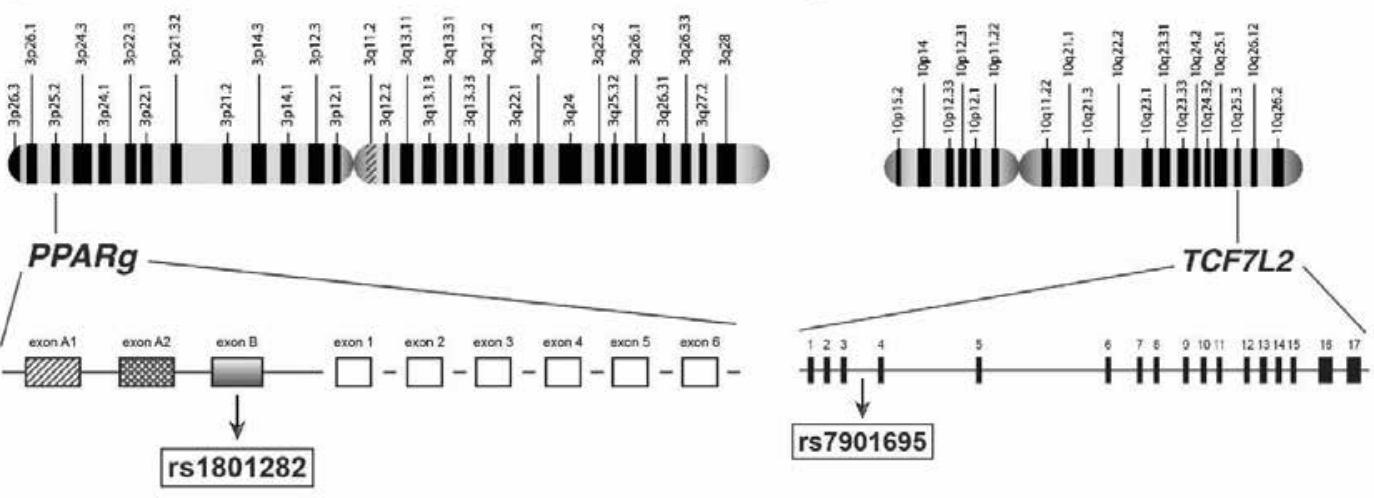

Figure 1. Genomic structure of the studied genes and the location of the selected polymorphisms. rs: reference sequence. (A) FTO: fat mass and obesity associated gene. (B) LEPR: leptin receptor gene. (C) PPARg: peroxisome proliferator-activated receptor gamma gene. (D) TCF7L2: transcription factor 7-like 2 gene.

control of food intake and energy balance (7). Because of the relationship between FTO and obesity, several studies have been conducted to verify the association of FTO polymorphisms and T2DM $(8,9)$. In certain populations, FTO variants increase susceptibility to T2DM independent of their effect on weight gain, suggesting that changes in the environment or other genetic factors may contribute to the different associations observed between different ethnic groups (10).

Leptin is a hormone produced by adipocytes and other tissues such as the gastric mucosa, which acts as a signaling molecule in the regulation of body fat mass by negative feedback. Reaching the brain via the bloodstream, leptin acts on hypothalamic receptors thereby reducing appetite, stimulating energy consumption and the loss of body mass as well as the sympathetic nervous system (11). Leptin exerts its function by binding to leptin receptors $(\mathrm{Ob}-\mathrm{R})$. The soluble isoform of the Ob- $\mathrm{R}$ receptor, called $\mathrm{Ob}-\mathrm{Re}$, is generated by alternative splicing or by proteolytic cleavage of the membrane isoform. Leptin molecules may circulate as the free form or linked to Ob-R. This binding appears to postpone the action of leptin as the leptin-soluble receptor complex increases the half-life of leptin and modulates its action on target cells (12). Leptin receptors are encoded by the LEPR gene (13).

Leptin receptors are located mainly in the hypothalamus, but are also found in tissues and cells that regulate glucose homeostasis such as pancreatic beta cells. Therein, leptin receptors effect the inhibition of insulin secretion mediated by leptin. This behavior suggests $L E P R$ as a candidate gene for association with DM (14). Consistent with this, LEPR was recently identified as a strong candidate for GDM (15) and was therefore selected for our study.

Peroxisome proliferator activated receptors, known as PPARs, belong to the superfamily of hormonal nuclear receptors that act as transcription factors regulating gene expression. PPARs play a key role in regulating cell differentiation, the metabolism of 
glucose and lipids, and inflammation (16). In long periods of hypoglycemia, PPARs are involved in the supply of fatty acids and ketone bodies from adipose tissue as a source of energy. There are 3 subtypes of PPARs encoded by distinct genes: $\alpha, \beta / \delta$, and $\gamma$ (Figure 1). PPARy (PPARg) acts as a mediator of the link between lipid and glucose metabolism (17). Accordingly, PPARg agonists have been used in the treatment of dyslipidemia and hyperglycemia (18).

TCF7L2 is a transcription factor involved in stimulating the proliferation of pancreatic beta cells and the production of GLP-1, which stimulates insulin secretion (19). The TCF7L2 gene has been associated with T2DM in different populations (19-21). Common variants in intronic region of TCF7L2 have been identified as strong predictors of T2DM genetic risk (22). TCF7L2 polymorphisms modulate blood glucose and insulin secretion and the association of rs7901695 with GDM has previously been described in Caucasians (19). Another TCF7L2 polymorphism (rs7903146), which is in linkage disequilibrium with rs7901695, has been associated with GDM in Danish (23), Australian (21), Greek (5), and Swedish (20) populations.

\section{SUBJECTS AND METHODS}

This cross-sectional study was conducted with unrelated Euro-Brazilian pregnant women who attended a Public Hospital in Southern Brazil. The ethnic group classification was based on phenotype (pigmentation of the abdomen, hair color, and type and conformation of the nose and lips). Participants having white skin and European physical characteristics and/or self-reported the European ancestry was classified as Euro-Brazilians (24).

The Ethics Committee of the Federal University of Parana approved the study and written informed consent was obtained from the subjects.

Euro-Brazilians pregnant women with any gestational period were included in the study. Subjects with kidney (preeclampsia) disease, cardiovascular disease or infection disease were excluded.

The sample $(\mathrm{n}=252)$ was classified into two groups according to the 2015 criteria of the American Diabetes Association (1) and Brazilian Diabetes Association (2): healthy pregnant women (Control; $\mathrm{n}=125$ ) and patients with GDM $(\mathrm{n}=127)$. The groups were matched by age.

Clinical and anthropometric data were obtained from all subjects. Hypertension was defined according to the VI Brazilian Hypertension Guidelines (25), which consider hypertension in pregnancy when the systolic blood pressure $>140 \mathrm{mmHg}$ and/or diastolic blood pressure $>90 \mathrm{mmHg}$. No subjects were under antihypertensive treatment. Biochemical parameters were determined by routine laboratory methods using the automated system Architect ci8200 (Abbott Laboratórios do Brasil, Curitiba, PR, Brazil) with reagents, calibrators, and controls as recommended by the manufacturer. 1,5 anhydroglucitol concentrations were measured enzymatically (GlycoMark, Inc., New York, NY, USA). Glycated hemoglobin (HbAlc) was measured using Cobas Integra ${ }^{\circledR} 400$ Plus (Roche Diagnostica Brasil Ltda., São Paulo, SP, Brazil) with the AlC-2 Tina-Quant ${ }^{\circledR}$ Hemoglobin Alc Gen 2 reagent method certified by the National Glycohemoglobin Standardization Program.

DNA was extracted from whole blood using a modified "salting out" method (26) and the concentrations were normalized to $20 \mathrm{ng} / \mu \mathrm{L}$ for subsequent assays. Only samples with absorbance ratios $(280 / 260)$ between 1.8 and 2.0 (NanoDrop, ThermoScientific, Waltham, MA, USA) were used in this study. The polymorphisms were genotyped using real-time polymerase chain reaction (PCR) amplification with fluorescent probes as described in Table 1. Genotyping experiments were carried out using a 7500 Fast $^{\mathrm{TM}}$ Real-Time PCR System (Life Technologies/Applied Biosystems Foster City, CA, USA). The manufacturer provided the reagents (Master Mix $^{\circledR}$ and Genotyping Assay ${ }^{\circledR}$ SNPs) and other realtime PCR materials (Applied Biosystems). The reaction mixture $(8 \mu \mathrm{L}$ final volume) contained $3.0 \mu \mathrm{L}$ Master Mix (DNA polymerase, $\mathrm{Mg} 2+$, buffer, and additives), $0.1 \mu \mathrm{L}$ SNP Genotyping Assay (40X), $1.9 \mu \mathrm{L}$ ultrapure water, and $3.0 \mu \mathrm{L}$ genomic DNA at $20 \mathrm{ng} / \mu \mathrm{L}$. The cycle sequencing conditions were: 1 cycle of $1 \mathrm{~min}$ at $60^{\circ} \mathrm{C}$ (pre-PCR), 1 cycle of $10 \mathrm{~min}$ at $95^{\circ} \mathrm{C}, 45$ cycles of $15 \mathrm{~s}$ at $95^{\circ} \mathrm{C}$ followed by $60^{\circ} \mathrm{C}$ for $90 \mathrm{~s}$, and 1 final cycle of $30 \mathrm{~s}$ at $60^{\circ} \mathrm{C}$ (final extension). The quality of the genotyping was $98 \%$ or higher.

Normality was tested with the Kolmogorov-Smirnov test. Comparisons of parameters with normal distribution were performed using the Student t-test for independent samples or the Mann-Whitney U test for non-normally distributed variables. Categorical variables were compared using the Fisher exact test (two-tailed) or the Chi-square test, as appropriate. Allele frequencies and HardyWeinberg (HW) equilibrium were evaluated by the Chisquare test (http://ihg.gsf.de/cgi-bin/hw/hwal.pl). 
Table 1. Characteristics of the studied polymorphisms

\begin{tabular}{|c|c|c|c|c|c|c|}
\hline \multirow{2}{*}{$\begin{array}{l}\text { OMIM number } \\
610966\end{array}$} & \multirow{2}{*}{$\begin{array}{c}\text { Gene } \\
\text { FTO }\end{array}$} & \multirow{2}{*}{$\begin{array}{c}\text { Chromosome position } \\
16 q 12.2\end{array}$} & \multirow{2}{*}{$\begin{array}{c}\text { Location } \\
\text { Intron } 1\end{array}$} & \multicolumn{2}{|c|}{ Polymorphism } & TaqMan® probe \\
\hline & & & & rs1421085 & $\mathrm{C}>\mathrm{T}$ & C__8917103_10 \\
\hline \multirow[t]{2}{*}{601007} & $L E P R$ & $1 p 31.3$ & Exon 4 & rs1137100 & $A>G$ & C__518168_20 \\
\hline & & & Exon 6 & rs1137101 & $A>G$ & C__8722581_10 \\
\hline 601487 & PPARg & $3 p 25.2$ & Exon B & rs1801282 & $C>G$ & C__1129864_10 \\
\hline 602228 & TCF7L2 & $10 q 25.2-25.3$ & Intron 3 & rs7901695 & $C>T$ & C__384583_10 \\
\hline
\end{tabular}

OMIM: Online Mendelian Inheritance in Man $^{\circledR}$.

References: $(46,47)$.

Data analysis was performed using Statistica for Windows 8.0 software (StatSoft Inc., Tulsa, OK, USA), and a probability less than $5 \%(\mathrm{P}<0.05)$ was considered significant for all analyses.

\section{RESULTS}

Anthropometric and laboratorial data are presented in Table 2. The GDM group presented a higher body mass index $\left(32.7 \pm 5.0\right.$ vs $\left.26.9 \pm 6.3 \mathrm{~kg} / \mathrm{m}^{2} ; \mathrm{P}<0.001\right)$. The mean of systolic and diastolic blood pressure $(\mathrm{mmHg})$ for control and GDM groups were $108.8 \pm$ $13.3 / 68.7 \pm 9.2$ vs $118.4 \pm 12.9 / 73.8 \pm 10.5(\mathrm{P}<$ $0.001)$. The frequency of hypertension in subjects with GDM differed from the control group, being higher (14.9\% vs 4.8\%, respectively, $\mathrm{P}=0.007$ ). GDM group also had a higher family history of DM (approximately $70 \%)$ when compared with Euro-descendant healthy pregnant women from Portugal (16\%) (27) and France (19\%) (28). The median (control vs GDM) of fasting glucose and 2-h, $75 \mathrm{~g}$ glucose, 84 (79-88) vs 88 (81$95) \mathrm{mg} / \mathrm{dL}$ and 86.2 (79-102) vs 161.0 (149-176) $\mathrm{mg} / \mathrm{dL}$, showed higher concentration in GDM group $(\mathrm{P}<0.001)$. In GDM group no one of the patients were under insulin therapy. The lipid profile showed no difference between the groups $(\mathrm{P}>0.05)$, but triglycerides was higher in GDM group, 124.0 (96171) vs 221.0 (175-270) mg/dL ( $\mathrm{P}<0.001)$ (Table 2). The other parameters were within reference range for both groups.

The genotype and allele frequencies of the studied polymorphisms were not significantly different $(\mathrm{P}>$ 0.05 ) between the groups (Table 3 ). All genotypes were in Hardy-Weinberg equilibrium for both groups $(\mathrm{P}>0.05)$. One-way ANOVA and correlation analysis (Pearson) were applied to identify association and correlation between laboratory biomarkers described in Table 2 and the studied polymorphisms. Genotypes for all polymorphisms, coded 1 (common homozygous),
2 (heterozygous) and 3 (rare homozygous), showed no significance $(\mathrm{P}>0.05)$ for all analysis.

\section{DISCUSSION}

Elevated BMI is a strong predictor of GDM and insulin resistance (29). In the present study, pregnant women with GDM were found to be heavier than healthy pregnant women (Table 2). The rate of hypertension in the GDM group was higher than that reported in the literature, which is $5-10 \%(30,31)$. However, GDM group showed good glycemic control as assessed by a HbAlc median value of $5.6 \%$.

Notably, pregnant women with a family history for $\mathrm{DM}$ are at increased risk for developing GDM and for giving birth to macrosomic children $(32,33)$. GDM also induces a dyslipidemia state that is consistent with insulin resistance (34); triglycerides concentrations in particular were higher in the GDM group $(\mathrm{P}<0.001)$. Finally, although total protein, albumin, creatinine, urea and uric acid levels differed between the groups $(\mathrm{P}<0.001)$, they were within the reference range for these parameters and none of the subjects exhibited clinical symptoms of kidney disease or others pathologies. Pregnancy affects essentially all aspects of kidney physiology. Glomerular filtration rate (GFR) increases $50 \%$ as compared with nonpregnant levels (35) with subsequent decrease in serum creatinine, urea, and uric acid values (36). Also, increases in glomerular filtration rate and minor increases in urinary albumin excretion have been reported early in the course of diabetes $(37,38)$. These events, could explain the lower total proteins, albumin, creatinine and urea levels found in GDM compared to control group. The uric acid concentration in GDM was approximately $0.7 \mathrm{mg} / \mathrm{dL}$ higher than in control group (4.3 vs 3.6 $\mathrm{mg} / \mathrm{dL}, \mathrm{p}<0.00 \mathrm{l}$ ) (Table 2 ). This observations has been described in other studies and associated with insulin resistance and hypertension, which predominates in GDM group (39-41). 
Table 2. Anthropometric and laboratory characteristics of the studied groups

\begin{tabular}{|c|c|c|c|}
\hline Characteristics & Control $(n=125)$ & GDM $(n=127)$ & $\mathbf{P}$ \\
\hline Age, years & $30.6 \pm 4.7$ & $31.9 \pm 6.4$ & 0.070 \\
\hline Body mass indexa, $\mathrm{kg} / \mathrm{m}^{2}$ & $26.9 \pm 5.0$ & $32.7 \pm 6.3$ & $<0.001$ \\
\hline Hypertension, \% & 4.8 & 14.9 & $0.007^{\star}$ \\
\hline Family history for diabetes, $\%$ & - & 70.1 & - \\
\hline Fasting glucose, $\mathrm{mg} / \mathrm{dL}$ & $84.0(79-88)$ & 88 (81-95) & $<0.001^{\star *}$ \\
\hline 2-h $75 \mathrm{~g}$ glucose, $\mathrm{mg} / \mathrm{dL}$ & $86.2(79-102)$ & $161.0(149-176)$ & $<0.001^{\star \star}$ \\
\hline $\mathrm{HbA1c}, \%$ & - & $5.6(5.3-5.9)$ & - \\
\hline 1,5 anhydroglucitol, $\mu \mathrm{g} / \mathrm{mL}$ & $11.7 \pm 6.9$ & $9.8 \pm 5.1$ & 0.060 \\
\hline Total cholesterol, mg/dL & $213.9 \pm 50.0$ & $224.7 \pm 45.6$ & 0.074 \\
\hline HDL-cholesterol, mg/dL & $55.4 \pm 15.8$ & $56.8 \pm 12.5$ & 0.451 \\
\hline LDL-cholesterol, mg/dL & $130.9 \pm 41.5$ & $123.5 \pm 38.9$ & 0.146 \\
\hline Triglycerides, mg/dL & $124.0(96-171)$ & $221.0(175-270)$ & $<0.001^{\star \star}$ \\
\hline Total protein, $\mathrm{g} / \mathrm{dL}$ & $6.9 \pm 0.8$ & $6.4 \pm 0.5$ & $<0.001$ \\
\hline Albumin, g/dL & $4.2 \pm 0.6$ & $3.4 \pm 0.4$ & $<0.001$ \\
\hline Creatinine, mg/dL & $0.80(0.7-0.9)$ & $0.70(0.60-0.72)$ & $<0.001^{\star \star}$ \\
\hline Urea, mg/dL & $20.4 \pm 5.3$ & $16.1 \pm 4.8$ & $<0.001$ \\
\hline Uric acid, mg/dL & $3.6(3.0-3.9)$ & $4.3(3.7-4.9)$ & $<0.001^{\star *}$ \\
\hline
\end{tabular}

Values are presented as mean \pm SD, median (interquartile range) or \%; " -": no information available. Control: healthy pregnant women; GDM: gestational diabetes. a Pregnant BMI calculated at blood collection time. P-values, Student's t-test (independent variables), ${ }^{\star}$ Chi-square test or ${ }^{\star \star}$ Mann-Whitney U test.

Table 3. Genotype and allele frequencies of the genetic variants studied in the Control and GDM groups

\begin{tabular}{|c|c|c|c|c|}
\hline Gene/SNP & Genotypes & $\begin{array}{l}\text { Control } \\
n=125\end{array}$ & $\begin{array}{c}\text { GDM } \\
n=127\end{array}$ & $\mathbf{P}$ \\
\hline \multirow{5}{*}{$\begin{array}{l}\text { FTO } \\
\text { rs1421085 } \\
(C>T)\end{array}$} & TT & $53(42.4)$ & $52(40.9)$ & $0.420^{*}$ \\
\hline & $\mathrm{TC}$ & 52 (41.6) & $61(48.0)$ & \\
\hline & $\mathrm{CC}$ & $20(16.0)$ & $14(11.1)$ & \\
\hline & C-allele & 36.8 & 35.0 & 0.680 \\
\hline & {$[95 \% \mathrm{Cl}]$} & [31-43] & [29-41] & \\
\hline \multirow{5}{*}{$\begin{array}{l}\angle E P R \\
\text { rs1137100 } \\
(A>G)\end{array}$} & AA & $70(56.0)$ & 73 (57.5) & $0.687^{*}$ \\
\hline & $A G$ & 48 (38.4) & $50(39.4)$ & \\
\hline & $G G$ & $7(5.6)$ & $4(3.1)$ & \\
\hline & G-allele & 24.8 & 22.8 & 0.604 \\
\hline & [95\% Cl] & [19-30] & [18-28] & \\
\hline \multirow{5}{*}{$\begin{array}{l}\angle E P R \\
\text { rs } 1137101 \\
(A>G)\end{array}$} & $A A$ & $43(34.4)$ & 38 (29.9) & $0.228^{*}$ \\
\hline & $A G$ & $55(44.0)$ & $69(54.3)$ & \\
\hline & $\mathrm{GG}$ & 27 (21.6) & $20(15.8)$ & \\
\hline & G-allele & 43.6 & 42.9 & 0.876 \\
\hline & [95\% Cl] & [37-50] & [37-49] & \\
\hline \multirow{5}{*}{$\begin{array}{l}\text { PPARg } \\
\text { rs1801282 } \\
(\mathrm{C}>\mathrm{G})\end{array}$} & $\mathrm{CC}$ & $107(85.6)$ & $108(85.0)$ & $0.851^{*}$ \\
\hline & $C G$ & 17 (13.6) & 17 (13.4) & \\
\hline & $\mathrm{GG}$ & $1(0.8)$ & $2(1.6)$ & \\
\hline & G-allele & 7.6 & 8.3 & 0.782 \\
\hline & {$[95 \% \mathrm{Cl}]$} & [4-11] & [5-12] & \\
\hline \multirow{5}{*}{$\begin{array}{l}\text { TCF7L2 } \\
\text { rs7901695 } \\
(C>T)\end{array}$} & $\mathrm{TT}$ & $52(41.6)$ & $44(34.6)$ & $0.413^{\star}$ \\
\hline & СТ & $62(49.6)$ & 67 (52.8) & \\
\hline & $\mathrm{CC}$ & $11(8.8)$ & 16 (12.6) & \\
\hline & C-allele & 33.6 & 39.0 & 0.209 \\
\hline & {$[95 \% \mathrm{Cl}]$} & [28-39] & [33-45] & \\
\hline
\end{tabular}

Genotypes depicted as number (\%). 95\% Cl: Confidence interval of 95\%.

All polymorphisms were in Hardy-Weinberg equilibrium.

P: probability. Chi-square test or * Two tailed Fisher's Exact test. 


\section{FT0 rs1421085 polymorphism}

The FTO rs9939609 predisposes to childhood, adult $(42,43)$ and pregnancy obesity $(44)$. The FTO rs 1421085 polymorphism is associated with obesity in adults and in European and Chinese children (45) and with obesity and T2DM in African Americans (46). No information is available regarding its frequency in pregnant women or its association with GDM, underlying why this polymorphism was selected for analysis in the present study. However, the FTO rs1421085 polymorphism was not associated with GDM in the current population studied, nor with the parameters analyzed. The effect of sample size might have contributed to this result. Furthermore, the physiological effect of the presence of this intronic variant and the reported increased risk of obesity and DM need to be elucidated.

The frequency of the $\mathrm{C}$ allele on healthy pregnant women in this study was approximately two to threefold higher than the frequency reported in European, Chinese, and Japanese populations, whereas it was approximately 5 times lower than that reported in an African populations (HapMap - YRI). Brazilians are an admixture population. This genetic background could explain the differences of alleles frequencies when compared to others populations, even with populations with more similar ancestors such as Caucasians. Table 4 compares the reported risk allele frequencies in healthy subjects, including the current cohort of pregnant women, from different populations.

\section{LEPR rs1137100 and rs1137101 polymorphisms}

The LEPR rsl137100 polymorphism (K109R; Lys109Arg; 326A > G) is characterized by an A > G substitution resulting in a change of lysine to arginine at codon 109 (Figure 1). Caucasians with the AA genotype are 2 -fold more likely to develop T2DM than those with other genotypes (47). The LEPR rs1137101 polymorphism (Q223R; Gln223Arg; $668 \mathrm{~A}>\mathrm{G}$ ) is an $\mathrm{A}>\mathrm{G}$ substitution resulting in the exchange of glutamine for arginine at position 668 of LEPR (Figure 1). The presence of this variant was considered as an independent risk factor for T2DM in Malaysian subjects (48). Finns with glucose intolerance and the presence of the GG genotype (Finnish Diabetes Prevention Study) showed a higher risk for T2DM compared to those carrying the A allele. The rs1137100 and rs1137101 variants are each located in the region encoding the extracellular domain of the leptin receptor. The exchange of amino acids generated by the variants affects all receptor isoforms and might change the action of leptin toward insulin (49).

The allele frequency for rs $1137100 \mathrm{G}$ reported in the present studied was higher than the rate reported for Africans and significantly lower than that for Asians. The ethnic composition of the sample of this study (Euro-Brazilians) is the probable reason for the similarity with the frequencies reported for the English, French, and Europeans in general (Table 4). Elevated leptin concentrations are associated with adiposity and insulin resistance and it has been reported that individuals with the AA genotype of LEPR rs 1137100 showed higher concentrations than the G allele carriers. Although the function of this variant has not been elucidated, it was associated with the promotion of a change in the extracellular domain of the receptor that affects the leptin binding affinity (50). In this study it was not possible to verify the association of the polymorphism with obesity, BMI, or lipid or glucose changes (data not showed).

The frequency of $\mathrm{G}$ allele for rs 1137101 variant was similar to those reported for Europeans and lower than those of Africans (HapMap). Asian subjects presented a higher frequency of the G allele for rs1137101 than other populations, as shown in Table 4 . The variants rs1137100 and rs1137101 of LEPR were not associated with GDM in the studied population, nor with the analyzed parameters described in Table $2(\mathrm{P}>0.05)$.

\section{PPARg rs1801282 polymorphism}

The PPARg rs1801282 polymorphism results in a substitution of proline for alanine at codon 12 of exon B (C > G; Prol2Ala; Figure 1). This polymorphism causes a conformational change in the protein, and the presence of the minor allele is associated with a reduction in the activity of PPARg (50). The rs1801282 C allele is associated with increased transcriptional activity of PPARg and, consequently, increased sensitivity to insulin. The association with T2DM is controversial, as some studies have found a positive association while others showed that the presence of the variant conferred protection against T2DM (51). Similarly, some studies found no association of rs 1801282 with $\operatorname{GDM}(5,23)$. In a study conducted in Turkey, this polymorphism had no effect on the prevalence of GDM or glucose concentrations in pregnant women, but its presence 
impacted the weight of pregnant women with GDM (52). The presence of the rs1801282 GG genotype was associated with a higher BMI before pregnancy and a higher pre-pregnancy obesity rate, but was related to a $50 \%$ reduction in the risk of developing GDM in a French population (53).

Table 4. Comparison between the allele frequencies of healthy pregnant women from the current study with those obtained from healthy subjects in other studies

\begin{tabular}{|c|c|c|c|c|c|c|c|}
\hline \multirow{3}{*}{ Population } & \multicolumn{6}{|c|}{ FTO rs1421085 polymorphism } & \multirow{3}{*}{ Reference } \\
\hline & \multirow[t]{2}{*}{ Characteristics } & \multirow[t]{2}{*}{$\mathbf{n}$} & \multicolumn{3}{|c|}{$\begin{array}{c}\text { Genotype } \\
\text { (\%) }\end{array}$} & \multirow{2}{*}{$\begin{array}{c}\begin{array}{c}\text { Allele } \\
\text { (\%) }\end{array} \\
\text { C }\end{array}$} & \\
\hline & & & TT & TC & CC & & \\
\hline \multirow[t]{2}{*}{ Euro-Brazilian } & GDM & 127 & 40.9 & 48.0 & 11.1 & 35.0 & \multirow[t]{2}{*}{ Present work } \\
\hline & Controls & 125 & 42.4 & 41.6 & 16.0 & 36.8 & \\
\hline Chinese Han & & 90 & 70.7 & 24.4 & 4.9 & 11.6 & HapMap-HCB \\
\hline European & & 180 & 27.4 & 53.1 & 19.5 & 16.7 & HapMap-CEU \\
\hline Japanese & & 91 & 67.1 & 28.2 & 4.7 & 18.8 & HapMap-JPT \\
\hline \multirow[t]{2}{*}{ Turkish } & Obeses & 190 & 30.5 & 51.1 & 18.4 & 43.9 & \multirow[t]{2}{*}{$(48)$} \\
\hline & Controls & 97 & 28.8 & 52.6 & 18.6 & 44.8 & \\
\hline Caucasian & Obeses & & 29.5 & 30.5 & 40 & 55.2 & (49) \\
\hline \multirow[t]{2}{*}{ African } & & 90 & 86.7 & 13.3 & 0 & 6.6 & HapMap-YRI \\
\hline & \multicolumn{5}{|c|}{ LEPR rs1137100 polymorphism } & & \\
\hline \multirow{2}{*}{ Population } & \multirow{2}{*}{ Characteristics } & \multirow[t]{2}{*}{$\mathbf{N}$} & \multicolumn{3}{|c|}{$\begin{array}{c}\text { Genotype } \\
\text { (\%) }\end{array}$} & $\begin{array}{c}\text { Allele } \\
\text { (\%) }\end{array}$ & \multirow{2}{*}{ Reference } \\
\hline & & & AA & $\mathbf{A G}$ & GG & G & \\
\hline \multirow[t]{2}{*}{ Euro-Brazilian } & GDM & 127 & 57.5 & 39.4 & 3.1 & 22.8 & \multirow[t]{2}{*}{ Present work } \\
\hline & Controls & 125 & 56.0 & 38.4 & 5.6 & 24.8 & \\
\hline African & & 90 & 69.6 & 27.7 & 2.7 & 16.5 & HapMap-YRI \\
\hline \multirow[t]{2}{*}{ French } & Obeses & 877 & 56.7 & 37.4 & 5.9 & 24.6 & \multirow[t]{2}{*}{ (50) } \\
\hline & Controls & 877 & 53.4 & 39.2 & 7.4 & 27.0 & \\
\hline \multirow[t]{2}{*}{ British } & Obeses & 190 & 54.0 & 38.0 & 8.0 & 27.4 & \multirow[t]{2}{*}{ (51) } \\
\hline & Controls & 132 & 55.0 & 39.0 & 6.0 & 25.8 & \\
\hline European & & 180 & 49.6 & 42.5 & 8.0 & 29.2 & HapMap-CEU \\
\hline Brazilians & Hypertension & 470 & 42.8 & 46.8 & 10.4 & 33.8 & (52) \\
\hline Chinese Han & & 90 & 2.5 & 27.5 & 70.0 & 83.7 & HapMap-HCB \\
\hline \multirow[t]{2}{*}{ Japanese } & & 91 & 2.5 & 40.2 & 57.3 & 97.4 & HapMap-JPT \\
\hline & \multicolumn{5}{|c|}{ LEPR rs1137101 polymorphism } & & \\
\hline Population & Characteristics & $\mathbf{N}$ & & $\begin{array}{c}\text { Genotype } \\
\text { (\%) }\end{array}$ & & $\begin{array}{c}\text { Allele } \\
\text { (\%) }\end{array}$ & Reference \\
\hline & & & AA & $\mathbf{A G}$ & GG & G & \\
\hline Euro-Brazilian & GDM & 127 & 29.9 & 54.3 & 15.8 & 42.9 & Present work \\
\hline & Controls & 125 & 34.4 & 44.0 & 21.6 & 43.6 & \\
\hline French & Obeses & 877 & 31.6 & 50.0 & 18.4 & 43.4 & (50) \\
\hline & Controls & 877 & 31.6 & 47.1 & 21.3 & 44.9 & \\
\hline British & Obeses & 190 & 29.0 & 53.0 & 18.0 & 44.6 & (51) \\
\hline & Controls & 132 & 28.0 & 58.0 & 14.0 & 42.8 & \\
\hline European & & 180 & 25.9 & 53.6 & 20.5 & 47.3 & HapMap-CEU \\
\hline African & & 90 & 11.1 & 58.3 & 30.6 & 59.7 & HapMap-YRI \\
\hline Japanese & & 91 & 1.2 & 30.5 & 68.3 & 83.5 & HapMap-JPT \\
\hline Chinese Han & & 90 & 2.2 & 17.8 & 80.0 & 88.9 & HapMap-HCB \\
\hline
\end{tabular}




\begin{tabular}{|c|c|c|c|c|c|c|c|}
\hline \multirow{3}{*}{ Population } & \multicolumn{5}{|c|}{ PPARg rs1801282 polymorphism } & \multirow{3}{*}{$\begin{array}{c}\begin{array}{c}\text { Allele } \\
\text { (\%) }\end{array} \\
\mathbf{G}\end{array}$} & \multirow{3}{*}{ Reference } \\
\hline & \multirow[t]{2}{*}{ Characteristics } & \multirow[t]{2}{*}{ n } & \multicolumn{3}{|c|}{$\begin{array}{l}\text { Genotype } \\
\text { (\%) }\end{array}$} & & \\
\hline & & & CC & CG & GG & & \\
\hline \multirow[t]{2}{*}{ Euro-Brazilian } & GDM & 127 & 85 & 13.4 & 1.6 & 8.3 & Present work \\
\hline & Controls & 125 & 85.6 & 13.6 & 0.8 & 7.6 & \\
\hline French & $\begin{array}{l}\text { Mothers with } \\
\text { glucose tolerance }\end{array}$ & 1708 & 80 & 19 & 1 & 10.4 & (42) \\
\hline \multirow[t]{2}{*}{ Danish } & GDM & 283 & 75.8 & 22.6 & 1.6 & 12.8 & (22) \\
\hline & $\begin{array}{c}\text { Women with glucose } \\
\text { tolerance }\end{array}$ & 2446 & 75.2 & 22.7 & 2.1 & 13.5 & \\
\hline \multirow[t]{2}{*}{ Danish } & T2DM & 1461 & 76 & 22 & 2 & 13.0 & (53) \\
\hline & Controls & 4986 & 75 & 23 & 2 & 13.9 & \\
\hline \multirow[t]{2}{*}{ Italian } & $\begin{array}{l}\text { Peripheral arterial } \\
\text { disease }\end{array}$ & 201 & 74.1 & 23.9 & 2.0 & 14.0 & (54) \\
\hline & Controls & 201 & 84.6 & 14.9 & 0.5 & 8.0 & \\
\hline \multirow[t]{2}{*}{ Scandinavian } & GDM & 637 & 73.5 & 24.8 & 1.7 & 14.1 & (19) \\
\hline & Controls & 1232 & 74.5 & 24.2 & 1.3 & 13.4 & \\
\hline \multirow[t]{2}{*}{ Scandinavian } & GDM & 400 & 71.5 & 27.7 & 0.8 & 14.6 & (44) \\
\hline & Controls & 428 & 74.1 & 24.5 & 1.4 & 13.7 & \\
\hline \multirow[t]{2}{*}{ Arabs } & GDM & 100 & 91 & 9 & 0 & 4.5 & \\
\hline & Controls & 122 & 86.9 & 12.3 & 0.8 & 7.0 & \\
\hline \multirow[t]{2}{*}{ Turkish } & GDM & 62 & 80.7 & 19.3 & 0 & 19.4 & (41) \\
\hline & Controls & 100 & 84 & 16 & 0 & 16.0 & \\
\hline \multirow[t]{2}{*}{ Korean } & GDM & 94 & 94.6 & 5.4 & 0 & 2.7 & (55) \\
\hline & Controls & 41 & 82.9 & 17.1 & 0 & 8.5 & \\
\hline \multirow[t]{2}{*}{ Greek } & GDM & 148 & 96.6 & 3.4 & 0 & 3.0 & (5) \\
\hline & Controls & 107 & 93.5 & 6.5 & 0 & 2.0 & \\
\hline \multirow[t]{2}{*}{ Chinese } & GDM & 55 & 94.5 & 5.5 & 0 & 3.0 & (56) \\
\hline & Controls & 173 & 90.8 & 9.2 & 0 & 5.0 & \\
\hline \multirow[t]{2}{*}{ Korean } & GDM & 869 & 91.7 & 8.2 & 0.1 & 4.0 & (43) \\
\hline & Controls & 632 & 89.7 & 10.0 & 0.3 & 5.0 & \\
\hline \multicolumn{8}{|c|}{ TCF7L2 rs7901895 polymorphism } \\
\hline \multirow{2}{*}{ Population } & Characteristics & $\mathrm{n}$ & & $\begin{array}{c}\text { Genotype } \\
\text { (\%) }\end{array}$ & & $\begin{array}{l}\text { Allele } \\
\text { (\%) }\end{array}$ & Reference \\
\hline & & & TT & TC & CC & C & \\
\hline \multirow[t]{2}{*}{ Euro-Brazilian } & GDM & 127 & 34.6 & 52.8 & 12.6 & 39.0 & Present work \\
\hline & Controls & 125 & 41.6 & 49.6 & 8.8 & 33.6 & \\
\hline Chinese Han & & 90 & 95.3 & 4.7 & 0 & 2.3 & HарМар-HCB \\
\hline \multirow[t]{2}{*}{ Swedish women } & GDM & 1102 & 51.2 & 34.2 & 7.6 & 26.5 & (45) \\
\hline & Controls & 794 & 34.2 & 43.1 & 11.5 & 34.4 & \\
\hline Swedish men & T2DM & 825 & 52.6 & 39.9 & 7.5 & 27.5 & (57) \\
\hline & Controls & 793 & 59.2 & 36.0 & 4.8 & 22.8 & \\
\hline European & & 180 & 54.5 & 34.8 & 10.7 & 28.1 & HapMap-CEU \\
\hline Japanese & & 91 & 94.2 & 4.7 & 0.1 & 3.5 & HарМар-JPT \\
\hline Caucasian & GDM & - & - & - & - & 30 & (18) \\
\hline African-American & GDM & - & - & - & - & 40 & \\
\hline Spanish & GDM & 45 & 38 & 44 & 18 & 40 & (58) \\
\hline & Controls & 25 & 40 & 52 & 8 & 34 & \\
\hline African & & 90 & 27.4 & 56.5 & 15.9 & 44.2 & HapMap-YRI \\
\hline
\end{tabular}

Allele frequencies are presented as \% [95\% confidence interval]. The frequencies of the minor allele (T) that differ from the confidence interval $(95 \%)$ for the healthy group of the current study are highlighted in bold. 
PPARg rs1801282 was not associated with GDM in the current studied population, nor with the analyzed parameters described in Table $2(\mathrm{P}>0.05)$. In accordance with the results of our study, no association of the variant with GDM was found in Korean (54), Scandinavian, or Arab pregnant women (55). The G allele frequencies observed in this study were similar to the French and greater than those reported for the Arab, Greek, Korean, and Chinese populations, whereas Danish, Scandinavian and Turkish populations showed a higher frequency of the $\mathrm{G}$ allele (Table 4). Regional population differences might explain these findings.

\section{TCF7L2 rs7901695 polymorphism}

The $\mathrm{T}$ allele of rs7901695 conferred increased risk for GDM in American Caucasians, with an odds ratio of 1.98 (19). In Swedish patients with GDM the CT and CC genotypes of rs7901695 showed a strong association with GDM even after adjusting for maternal age, number of pregnancies, and family history of DM and HLA-DQ genotypes (56). Based on this information, we expected to find an association between the rs7901695 polymorphism and GDM in the current studied population, but this was not observed.

The rs7901895 C allele is more common in African populations. The frequency found in healthy pregnant women in the present study is similar to those reported for Europeans in general and for Swedish and Spanish pregnant women. In this study, pregnant women with GDM showed allele frequencies similar to those of Spanish, Caucasian, and African American women with GDM, and slightly higher than those of Swedish women with GDM (Table 4). In contrast, less than $5 \%$ of the Asian population carries the $\mathrm{C}$ allele. Ethnicity-specific factors might be responsible for these differences.

In conclusion, the FTO rs1421085, LEPR rsl137100 and rsll37101, PPARg rsl801282, and TCF7L2 rs7901695 polymorphisms were not associated with GDM in a Brazilian population, nor with the other parameters analyzed. The data from this study will likely contribute to the understanding the potential roles of these variants across populations; however, further research is required to identify the underlying factors influencing the risk of GDM in the Brazilian white population.

Disclosure: no potential conflict of interest relevant to this article was reported.

\section{REFERENCES}

1. ADA. (2) Classification and diagnosis of diabetes. Diabetes Care. 2015;38 Suppl:S8-16.

2. SBD. Diretrizes SBD. Sociedade Brasileira de Diabetes. 2015. Available from: <http://www.diabetes.org.br/sbdonline/images/ docs/DIRETRIZES-SBD-2015-2016.pdf>. Accessed on: Apr. 20, 2016.

3. Buchanan TA, Xiang AH, Page KA. Gestational diabetes mellitus: risks and management during and after pregnancy. Nat Rev Endocrinol. 2012;8(11):639-49.

4. Baz B, Riveline JP, Gautier JF. ENDOCRINOLOGY OF PREGNANCY: Gestational diabetes mellitus: definition, aetiological and clinical aspects. Eur J Endocrinol. 2016;174(2):R43-51.

5. Pappa KI, Gazouli M, Economou K, Daskalakis G, Anastasiou E, Anagnou NP, et al. Gestational diabetes mellitus shares polymorphisms of genes associated with insulin resistance and type 2 diabetes in the Greek population. Gynecol Endocrinol. 2011;27(4):267-72.

6. Robitaille J, Grant AM. The genetics of gestational diabetes mellitus: evidence for relationship with type 2 diabetes mellitus. Genet Med. 2008;10(4):240-50.

7. Merkestein M, Laber S, McMurray F, Andrew D, Sachse G, Sanderson J, et al. FTO influences adipogenesis by regulating mitotic clonal expansion. Nat Commun. 2015;6:6792.

8. Field SF, Howson JM, Walker NM, Dunger DB, Todd JA. Analysis of the obesity gene FTO in 14,803 type 1 diabetes cases and controls. Diabetologia. 2007;50(10):2218-20.

9. Legry V, Cottel D, Ferrieres J, Arveiler D, Andrieux N, Bingham A, et al. Effect of an FTO polymorphism on fat mass, obesity, and type 2 diabetes mellitus in the French MONICA Study. Metabolism. 2009;58(7):971-5.

10. Larder R, Cheung MK, Tung YC, Yeo GS, Coll AP. Where to go with FTO? Trends Endocrinol Metab. 2011;22(2):53-9.

11. Oswal A, Yeo G. Leptin and the control of body weight: a review of its diverse central targets, signaling mechanisms, and role in the pathogenesis of obesity. Obesity (Silver Spring). 2010;18(2):221-9.

12. Cammisotto $P$, Bendayan $M$. A review on gastric leptin: the exocrine secretion of a gastric hormone. Anat Cell Biol. 2012;45(1):1-16.

13. Winick JD, Stoffel M, Friedman JM. Identification of microsatellite markers linked to the human leptin receptor gene on chromosome 1. Genomics. 1996;36(1):221-2.

14. Emilsson V, Liu YL, Cawthorne MA, Morton NM, Davenport M. Expression of the functional leptin receptor mRNA in pancreatic islets and direct inhibitory action of leptin on insulin secretion. Diabetes. 1997;46(2):313-6.

15. Zhang $\mathrm{Q}$, He M, Wang J, Liu S, Cheng $H$, Cheng Y. Predicting of disease genes for gestational diabetes mellitus based on network and functional consistency. Eur J Obstet Gynecol Reprod Biol. 2015;186:91-6.

16. VargaT, Czimmerer Z, Nagy L. PPARs are a unique set of fatty acid regulated transcription factors controlling both lipid metabolism and inflammation. Biochim Biophys Acta. 2011;1812(8):1007-22.

17. Janani C, Ranjitha Kumari BD. PPAR gamma gene--a review. Diabetes Metab Syndr. 2015;9(1):46-50.

18. Li Y, Qi Y, Huang TH, Yamahara J, Roufogalis BD. Pomegranate flower: a unique traditional antidiabetic medicine with dual PPAR-alpha/-gamma activator properties. Diabetes Obes Metab. 2008;10(1):10-7.

19. Stuebe AM, Wise A, Nguyen T, Herring A, North KE, Siega-Riz AM. Maternal genotype and gestational diabetes. Am J Perinatol. 2014;31(1):69-76.

20. Shaat N, Lernmark A, Karlsson E, Ivarsson S, Parikh H, Berntorp $\mathrm{K}$, et al. A variant in the transcription factor 7-like 2 (TCF7L2) 
gene is associated with an increased risk of gestational diabetes mellitus. Diabetologia. 2007;50(5):972-9.

21. Freathy RM, Hayes MG, Urbanek M, Lowe LP, Lee $H$, Ackerman $C$, et al. Hyperglycemia and Adverse Pregnancy Outcome (HAPO) study: common genetic variants in GCK and TCF7L2 are associated with fasting and postchallenge glucose levels in pregnancy and with the new consensus definition of gestational diabetes mellitus from the International Association of Diabetes and Pregnancy Study Groups. Diabetes. 2010;59(10):2682-9.

22. Cauchi S, El AchhabY, Choquet H, Dina C, Krempler F, Weitgasser $R$, et al.TCF7L2 is reproducibly associated with type 2 diabetes in various ethnic groups: a global meta-analysis. J Mol Med (Berl). 2007;85(7):777-82.

23. Lauenborg J, Grarup N, Damm P, Borch-Johnsen K, Jorgensen $\mathrm{T}$, Pedersen $\mathrm{O}$, et al. Common type 2 diabetes risk gene variants associate with gestational diabetes. J Clin Endocrinol Metab. 2009;94(1):145-50.

24. Krieger H, Morton NE, Mi MP, Azevedo E, Freire-Maia A, Yasuda N. Racial admixture in north-eastern Brazil. Ann Hum Genet. 1965;29(2):113-25.

25. Sociedade Brasileira de Cardiologia; Sociedade Brasileira de Hipertensão; Sociedade Brasileira de Nefrologia. VI Brazilian Guidelines on Hypertension. Arq Bras Cardiol. 2010;95(1 Suppl):1-51.

26. Lahiri DK, Nurnberger JI, Jr. A rapid non-enzymatic method for the preparation of HMW DNA from blood for RFLP studies. Nucleic Acids Res. 1991;19(19):5444.

27. Ribeiro AMC, Nogueira-Silva C, Melo-Rochae G, Pereira ML, Rocha A. Diabetes gestacional: determinação de fatores de risco para diabetes mellitus. Rev Port Endocrinol Diabetes Metab. 2015;10(1):6.

28. Miailhe G, Kayem G, Girard G, Legardeur H, Mandelbrot L. Selective rather than universal screening for gestational diabetes mellitus? Eur J Obstet Gynecol Reprod Biol. 2015;191:95-100.

29. Basraon SK, Mele L, Myatt L, Roberts JM, Hauth JC, Leveno KJ, et al. Relationship of Early Pregnancy Waist-to-Hip Ratio versus Body Mass Index with Gestational Diabetes Mellitus and Insulin Resistance. Am J Perinatol. 2016;33(1):114-21.

30. Cho GJ, Park JH, Lee H, Yoo S, Shin SA, Oh MJ. Prepregnancy Factors as Determinants of the Development of Diabetes Mellitus After First Pregnancy. J Clin Endocrinol Metab. 2016;101(7): 2923-30.

31. Shahbazian H, Nouhjah S, Shahbazian N, Jahanfar S, Latifi SM, Aleali A, et al. Gestational diabetes mellitus in an Iranian pregnant population using IADPSG criteria: Incidence, contributing factors and outcomes. Diabetes Metab Syndr. 2016;10(4):242-6.

32. Zhang $C$, Ning Y. Effect of dietary and lifestyle factors on the risk of gestational diabetes: review of epidemiologic evidence. Am J Clin Nutr. 2011;94(6 Suppl):1975S-9S.

33. Ben-Haroush A, Yogev Y, Hod M. Epidemiology of gestational diabetes mellitus and its association with Type 2 diabetes. Diabet Med. 2004;21(2):103-13.

34. Ryckman KK, Spracklen CN, Smith CJ, Robinson JG, Saftlas AF. Maternal lipid levels during pregnancy and gestational diabetes: a systematic review and meta-analysis. BJOG. 2015;122(5): 643-51.

35. DunlopW. Serial changes in renal haemodynamics during normal human pregnancy. Br J Obstet Gynaecol. 1981;88(1):1-9.

36. Cheung KL, Lafayette RA. Renal physiology of pregnancy. Adv Chronic Kidney Dis. 2013;20(3):209-14.

37. Mogensen CE. Microalbuminuria as a predictor of clinical diabetic nephropathy. Kidney Int. 1987;31(2):673-89.

38. Parving HH, Viberti GC, Keen H, Christiansen JS, Lassen NA. Hemodynamic factors in the genesis of diabetic microangiopathy. Metabolism. 1983;32(9):943-9.
39. Seghieri G, Breschi MC, Anichini R, De Bellis A, Alviggi L, Maida I, et al. Serum homocysteine levels are increased in women with gestational diabetes mellitus. Metabolism. 2003;52(6):720-3.

40. Yoo TW, Sung KC, Shin HS, Kim BJ, Kim BS, Kang JH, et al. Relationship between serum uric acid concentration and insulin resistance and metabolic syndrome. Circ J. 2005;69(8):928-33.

41. Santos IC, Frigeri HR, Rea RR, Almeida AC, Souza EM, Pedrosa $\mathrm{FO}$, et al. The glucokinase gene promoter polymorphism -30G $>\mathrm{A}$ (rs1799884) is associated with fasting glucose in healthy pregnant women but not with gestational diabetes. Clin Chim Acta. 2010;411(11-12):892-3.

42. Frayling TM, Timpson NJ, Weedon MN, Zeggini E, Freathy $\mathrm{RM}$, Lindgren CM, et al. A common variant in the FTO gene is associated with body mass index and predisposes to childhood and adult obesity. Science. 2007;316(5826):889-94.

43. Dina C, Meyre D, Gallina S, Durand E, Korner A, Jacobson P, et al. Variation in FTO contributes to childhood obesity and severe adult obesity. Nat Genet. 2007;39(6):724-6.

44. Martins MC, Trujillo J, Farias DR, Struchiner CJ, Kac G. Association of the FTO (rs9939609) and MC4R (rs17782313) gene polymorphisms with maternal body weight during pregnancy. Nutrition. 2016;32(11-12):1223-30.

45. Wang L, Yu Q, Xiong Y, Liu L, Zhang X, Zhang Z, et al. Variant rs 1421085 in the FTO gene contribute childhood obesity in Chinese children aged 3-6 years. Obes Res Clin Pract. 2013;7(1):e14-22.

46. Bressler J, Kao WH, Pankow JS, Boerwinkle E. Risk of type 2 diabetes and obesity is differentially associated with variation in FTO in whites and African-Americans in the ARIC study. PloS One. 2010;5(5):e10521.

47. Salopuro T, Pulkkinen L, Lindstrom J, Eriksson JG, Valle TT, Hamalainen $\mathrm{H}$, et al. Genetic variation in leptin receptor gene is associated with type 2 diabetes and body weight:The Finnish Diabetes Prevention Study. Int J Obes (Lond). 2005;29(10): 1245-51.

48. Etemad A, Ramachandran V, Pishva SR, Heidari F, Aziz AF, Yusof $A K$, et al. Analysis of GIn223Agr polymorphism of Leptin Receptor Gene in type II diabetic mellitus subjects among Malaysians. Int J Mol Sci. 2013;14(9):19230-44.

49. Tabassum R, Mahendran $Y$, Dwivedi OP, Chauhan G, Ghosh $\mathrm{S}$, Marwaha RK, et al. Common variants of IL6, LEPR, and PBEF1 are associated with obesity in Indian children. Diabetes. 2012;61(3):626-31.

50. Meirhaeghe A, Amouyel P. Impact of genetic variation of PPARgamma in humans. Mol Genet Metab. 2004;83(1-2):93-102.

51. Groop L, Pociot F. Genetics of diabetes--are we missing the genes or the disease? Mol Cell Endocrinol. 2014;382(1):726-39.

52. Tok EC, Ertunc D, Bilgin O, Erdal EM, Kaplanoglu M, Dilek S. PPAR-gamma2 Pro12Ala polymorphism is associated with weight gain in women with gestational diabetes mellitus. Eur $\mathrm{J}$ Obstet Gynecol Reprod Biol. 2006;129(1):25-30.

53. Heude B, PellouxV, Forhan A, Bedel JF, Lacorte JM, Clement K, et al. Association of the Pro12Ala and C1431T variants of PPARgamma and their haplotypes with susceptibility to gestational diabetes. $J$ Clin Endocrinol Metab. 2011;96(10):E1656-60.

54. Cho YM, Kim TH, Lim S, Choi SH, Shin HD, Lee HK, et al. Type 2 diabetes-associated genetic variants discovered in the recent genome-wide association studies are related to gestational diabetes mellitus in the Korean population. Diabetologia. 2009;52(2):253-61.

55. Shaat N, Ekelund M, Lernmark A, Ivarsson S, Nilsson A, Perfekt $R$, et al. Genotypic and phenotypic differences between Arabian and Scandinavian women with gestational diabetes mellitus. Diabetologia. 2004;47(5):878-84.

56. Papadopoulou A, Lynch KF, Shaat N, Hakansson R, Ivarsson SA Berntorp $\mathrm{K}$, et al. Gestational diabetes mellitus is associated 
with TCF7L2 gene polymorphisms independent of HLADQB1*0602 genotypes and islet cell autoantibodies. Diabet Med. 2011;28(9):1018-27.

57. NCBI. dbSNP Short Genetic Variantions 2013 [Available from: http:// www.ncbi.nlm.nih.gov/SNP/snp_ref.cgi?searchType=adhoc search\&type=rs\&rs=rs5393.

58. OMIM. Online Mendelian Inheritance in Man 2014 [Available from: http://www.omim.org/.

59. Solak M, Ozdemir Erdogan M, Yildiz SH, Ucok K, Yuksel S, Arikan Terzi ES, et al. Association of obesity with rs 1421085 and rs9939609 polymorphisms of FTO gene. Molecular biology reports. 2014;41(11):7381-6.

60. Harbron J, van der Merwe L, Zaahl MG, Kotze MJ, Senekal M. Fat mass and obesity-associated (FTO) gene polymorphisms are associated with physical activity, food intake, eating behaviors, psychological health, and modeled change in body mass index in overweight/obese Caucasian adults. Nutrients. 2014;6(8):3130-52.

61. Phillips CM, Goumidi L, Bertrais S, Field MR, Ordovas JM, Cupples LA, et al. Leptin receptor polymorphisms interact with polyunsaturated fatty acids to augment risk of insulin resistance and metabolic syndrome in adults. J Nutr. 2010;140(2):238-44.

62. Gotoda T, Manning BS, Goldstone AP, Imrie H, Evans AL, Strosberg $A D$, et al. Leptin receptor gene variation and obesity: lack of association in a white British male population. Hum Mol Genet. 1997;6(6):869-76.

63. Pena G, Guimaraes AL, Veloso RR, Reis TC, Gomes CS, Neto JF, et al. Leptin Receptor Gene GIn223Arg Polymorphism Is Not
Associated with Hypertension: A Preliminary Population-Based Cross-Sectional Study. Cardiol Res Pract. 2014;2014:879037.

64. Hansen SK, Nielsen EM, Ek J, Andersen G, Glumer C, Carstensen $B$, et al. Analysis of separate and combined effects of common variation in KCNJ11 and PPARG on risk of type 2 diabetes. J Clin Endocrinol Metab. 2005;90(6):3629-37.

65. Catalano M, Cortelazzo A, Santi R, Contino L, Demicheli M, Yilmaz $\mathrm{Y}$, et al. The Pro12Ala polymorphism of peroxisome proliferatoractivated receptor-gamma2 gene is associated with plasma levels of soluble RAGE (Receptor for Advanced Glycation Endproducts) and the presence of peripheral arterial disease. Clin Biochem. 2008;41(12):981-5.

66. Chon SJ, Kim SY, Cho NR, Min DL, Hwang YJ, Mamura M. Association of variants in PPARgamma(2), IGF2BP2, and KCNQ1 with a susceptibility to gestational diabetes mellitus in a Korean population. Yonsei Med J. 2013;54(2):352-7.

67. Cheng $Y$, Ma Y, Peng T, Wang J, Lin R, Cheng HD. [Genotype discrepancy between maternal and fetal Pro12Ala polymorphism of PPARG2 gene and its association with gestational diabetes mellitus]. Zhonghua Fu Chan Ke Za Zhi. 2010;45(3):170-3.

68. Mayans S, Lackovic K, Lindgren P, Ruikka K, Agren A, Eliasson M, et al.TCF7L2 polymorphisms are associated with type 2 diabetes in northern Sweden. Eur J Hum Genet. 2007;15(3):342-6.

69. Pagan A, Sabater-Molina M, Olza J, Prieto-Sanchez MT, BlancoCarnero JE, Parrilla JJ, et al. A gene variant in the transcription factor 7-like 2 (TCF7L2) is associated with an increased risk of gestational diabetes mellitus. Eur J Obstet Gynecol Reprod Biol. 2014;180:77-82. 